Abstracta Iranica Abstracta Iranica

Revue bibliographique pour le domaine irano-aryen

Volume 29 | 2008

Comptes rendus des publications de 2006

\title{
"Some observations on the pottery from the Islamic Settlement of Udegram, Swat ». East and West, 56/1-3, September 2006, pp. 229-236.
}

\section{Monik Kervran}

\section{(2) OpenEdition}

Journals

Édition électronique

URL : http://journals.openedition.org/abstractairanica/29382

DOI : 10.4000/abstractairanica.29382

ISSN : 1961-960X

Éditeur :

CNRS (UMR 7528 Mondes iraniens et indiens), Éditions de l'IFRI

Édition imprimée

Date de publication : 15 mai 2008

ISSN : 0240-8910

Référence électronique

Monik Kervran, « «Some observations on the pottery from the Islamic Settlement of Udegram, Swat ». East and West, 56/1-3, September 2006, pp. 229-236. », Abstracta Iranica [En ligne], Volume 29 | 2008, document 247, mis en ligne le 15 septembre 2008, consulté le 25 septembre 2020. URL : http:// journals.openedition.org/abstractairanica/29382; DOI : https://doi.org/10.4000/abstractairanica. 29382

Ce document a été généré automatiquement le 25 septembre 2020.

Tous droits réservés 
«Some observations on the pottery from the Islamic Settlement of Udegram, Swat ». East and West, 56/1-3, September 2006, pp. 229-236.

Monik Kervran

Introduction aux principaux types de céramique trouvés sur le site de Raja Gira. Trois catégories sont présentées : les pots de cuisson, les bols et jarres en céramique commune et deux types de céramiques glaçurées : les unes à décor d'engobe sous glaçure et les autres, des « sgraffiato ».

INDEX

Thèmes : 5.1. Monde iranophone

AUTEURS

MONIK KERVRAN

CNRS - Paris 